\title{
Identification of Bacterial Agents and Resistance Profile of Coagulase- Negative Staphylococci Isolated from Heifers Submitted or not to Precalving Treatment
}

Lucas Eduardo Pilon, Livia Castelani, Aline Francielle da Silva Santos, Mariana dos Santos Miranda, Luis Alberto Ambrosio, Claudia Rodrigues Pozzi and Juliana Rodrigues Pozzi Arcaro*

Centro Apta Bovinos de Leite, Instituto de Zootecnia, Nova Odessa, São Paulo, Brazil

\begin{abstract}
Identify the causative agents of mastitis present in the mammary glands of primiparous heifers submitted or not to precalving treatment and to determine the in vitro antimicrobial susceptibility profile of the CoNS isolates. Eightyseven animals were studied: Farm (1), 40 heifers, commercial farm, all treated precalving; Farm (2), 18 heifers; Farm (3), 29 animals. On Farms 2 and 3, the animals were divided into precalving treated and untreated groups. The treatments consisting of intramammary antibiotic infusion were administered 60 days before calving to all mammary quarters of each heifer after local antisepsis. Samples were collected during the precalving and calving period, 10 days after calving, and monthly. The results showed a predominance of CoNS during the precalving $(28.75 \%)$ and calving $(1.25 \%)$ period on Farm 1. On Farm 2, CoNS predominated during the precalving $(88.89 \%)$ and calving $(60 \%)$ period in untreated heifers; in the treated group, the precalving frequency of CoNS was $100 \%$. On Farm 3 , coagulase-positive Staphylococci (CoPS) predominated during the precalving and calving period in the untreated group $(69.24 \%$ and $39.28 \%$, respectively). The antibiogram revealed the following antibiotic resistance profiles: Farm 1 16.98\% ampicillin, and 2.83\% oxacillin; Farm 2 31.03\% penicillin and $17.24 \%$ oxacillin, and Farm $352.22 \%$ penicillin and $13.33 \%$ oxacillin. The presence of CoNS in the mammary gland of antibiotic-resistant heifers suggests these animals to be a source of infection in the herd.
\end{abstract}

Keywords: Mastitis; Heifers; Antibiotic resistance; Coagulasenegative Staphylococci

\section{Introduction}

Mastitis is defined as inflammation of the mammary gland, most often due to infection, and is considered to be the main cause of economic losses for dairy farmers and the dairy industry. Dairy farmers adopt preventive measures to control the disease in adult lactating or dry cows, while young animals are considered to be free of infection [1].

Studies have demonstrated the occurrence of intramammary infection in heifers during pregnancy, calving and or early lactation, and coagulase negative Staphylococci is the most prevalent. Second Vliegher et al. [2] to review studies the prevalence of IMI ranges between 29 and $75 \%$ of quarters before parturition, whereas the immediate prevalence postpartum ranges from 12 to over $57 \%$ of quarters infected, though in all studies a major proportion of infection was caused by coagulase negative Staphylococci.

Coagulases negative Staphylococci are gram-positive cocci are found in the skin of animals and man. Several studies have associated coagulase negative Staphylococci from human nosocomial infections and bovine mastitis [3]. Zhou et al. [4] found in milk samples from mammary quarters of lactating cows with mastitis strains resistant to penicillin $(18 / 18,100 \%)$, lincomycin $(18 / 18,100 \%)$, amoxicillin $(12 / 18$, $66.7 \%)$ and methicillin $(1 / 18,5.6 \%)$.

The objectives of the present study were to identify the causative agents of mastitis present in the mammary glands of primiparous heifers treated or not during the precalving and calving period and during lactation, to evaluate the efficiency of precalving treatment of primiparous heifer in reducing coagulase-negative Staphylococci (CoNS), and to determine the in vitro antimicrobial susceptibility profile of the CoNS isolates against the antibiotics most commonly used in veterinary medicine.

\section{Materials and Methods}

\section{Characteristics of the herd and animal management}

Eighty-seven dairy heifers were evaluated during the precalving and calving period and during lactation; 40 heifers belonged to a farm located in Descalvado, SP (Farm 1), 18 heifers were from an experimental farm in the Vale do Paraíba industrial region located in Pindamonhangaba, SP (Farm 2), and 29 animals belonged to the experimental farm of Instituto de Zootecnia, Nova Odessa, SP (Farm 3). On Farm 1, pre- and post-milking teat dipping in $10 \%$ chlorine solution is performed for teat disinfection. The other farms only perform post-milking teat dip in $5 \%$ glycerinated iodine.

\section{Treatments}

The treatments consisting of intramammary antibiotic infusion were administered 60 days before calving to all mammary quarters of each heifer after local antisepsis. The following treatment regimen was used on each farm:

Farm 1: Since this is a commercial farm, we chose not to modify the management adopted on the farm. The heifers received intramammary

*Corresponding author: Juliana Rodrigues Pozzi Arcaro, Centro Apta Bovinos de Leite, Instituto de Zootecnia, Nova Odessa, São Paulo, 13.460-000, Brazil, Tel: 55211934669423; E-mail: juarcaro@iz.sp.gov.br

Received September 29, 2016; Accepted October 10, 2016; Published October 14,2016

Citation: Pilon LE, Castelani L, Santos AFS, Miranda MS, Ambrosio LA, et al (2016) Identification of Bacterial Agents and Resistance Profile of CoagulaseNegative Staphylococci Isolated from Heifers Submitted or not to Precalving Treatment. J Vet Sci Technol 7: 390. doi: 10.4172/2157-7579.1000390

Copyright: ( 2016 Pilon LE, et al. This is an open-access article distributed under the terms of the Creative Commons Attribution License, which permits unrestricted use, distribution, and reproduction in any medium, provided the original author and source are credited. 
Citation: Pilon LE, Castelani L, Santos AFS, Miranda MS, Ambrosio LA, et al. (2016) Identification of Bacterial Agents and Resistance Profile of Coagulase-Negative Staphylococci Isolated from Heifers Submitted or not to Precalving Treatment. J Vet Sci Technol 7: 390. doi: 10.4172/2157-7579.1000390

Page 2 of 6

infusions of $0.25 \mathrm{~g}$ anhydrous Cefalonium, a semisynthetic beta-lactam antibiotic with bactericidal activity recommended for the treatment of dry cows.

Farm 2: Ten untreated animals (control group) and eight treated animals (treated group). The animals received intramammary infusions of an antibiotic with bactericidal activity of slow elimination and absorption, recommended for the treatment of dry cows (chemical composition: $677 \mathrm{mg}$ gentamicin sulfate).

Farm 3: Fourteen untreated animals (control group) and 15 treated animals (treated group). The animals received intramammary infusions of an antibiotic with bactericidal activity of slow elimination and absorption, recommended for the treatment of dry cows (chemical composition: $500.000 \mathrm{IU}$ penicillin $\mathrm{G}$ potassium, 1,000,000 IU penicillin $\mathrm{G}$ procaine, $0.732 \mathrm{~g}$ neomycin.

\section{Collection of biological material from heifers}

Samples were collected during the precalving and calving period, 10 days after calving, and monthly. Mammary secretions were collected from heifers 60 days before the estimated calving date following strict antisepsis routines. After collection, animals of the treated groups received the antibiotic. All samples (secretion, colostrum and milk) were collected into sterile tubes according to the recommendations of the National Mastitis Council (NMC) [5]. The tubes containing the samples were stored in isotherm boxes with ice cubes and sent to the laboratory for bacterial isolation and identification.

\section{Isolation and identification of microorganisms}

Milk aliquots $(10 \mu \mathrm{L})$ were incubated on plates containing $5 \%$ defibrinated sheep blood agar in a bacteriological oven at $37^{\circ} \mathrm{C}$ under aerobic conditions and were analyzed after 24 and $48 \mathrm{~h}$.

After incubation, the growth characteristics of the colonies on blood agar and the production of catalase were recorded. Next, colony morphology and Gram staining were observed. Colonies identified as catalase positive and Gram-positive cocci were submitted to slide coagulase tests using rabbit plasma [6]. Catalase-positive colonies and Gram-positive rods were classified as Corynebacterium spp. [7].

\section{Antimicrobial susceptibility testing}

The CoNS species identified were submitted to antimicrobial susceptibility testing according to the standards and recommendations of the National Committee for Clinical Laboratory Standards [8]. Disks impregnated with the following antibiotics were used: ceftiofur $(30 \mu \mathrm{g})$, neomycin $(10 \mu \mathrm{g})$, cephalexin $(30 \mu \mathrm{g})$, gentamicin $(10 \mu \mathrm{g})$, penicillin $(10 \mathrm{~g})$, florfenicol $(30 \mu \mathrm{g})$, oxacillin $(1 \mathrm{~g})$, ampicillin $(10 \mu \mathrm{g})$, and cefaclor $(30 \mathrm{~g})$.

\section{Statistical analysis}

To compare the differences between the prevalence of pathogens in treated and untreated groups, we used the $Z$ test for two proportions at $95 \%$ confidence. The null hypothesis of the $\mathrm{Z}$ test considers equality between the proportions and the alternative hypothesis considers that the proportions differ from each other. For two-sided $\mathrm{Z}$ test for two proportions we have: $\mathrm{H} 0$ : $\mathrm{p} 1-\mathrm{p} 2=0$; $\mathrm{H} 1: \mathrm{p} 1-\mathrm{p} 2 \neq 0$. Where, $\mathrm{p} 1$ (group of untreated heifers) and $\mathrm{p} 2$ (group of heifers) are the proportion of positive samples of milk for the occurrence of pathogens in the population $\mathrm{p} 1$ and $\mathrm{p} 2$, respectively, which represent the primiparous and $\mathrm{p} 0$ cows indicates that the difference between the two ratios is equal to zero. Software Minitab v. 13 was used for statistical analysis.

The odds ratio (OR), which is an association of intensity measurement was used to calculate how many times the prevalence of the pathogen in the treated group is lower than the prevalence of pathogens in the untreated group [9]. The odds ratio is calculated as the ratio $(\mathrm{a} / \mathrm{b}) /(\mathrm{c} / \mathrm{d})$ or $(\mathrm{d}) /(\mathrm{b}$ c) in the appendix (a) is presented in a didactic way. Calculate an estimate of the $95 \%$ confidence interval associated with the odds ratio. It conducted the statistical analysis using the Chi-square test to assess whether there was a significant difference in the $95 \%$ confidence level, when compared to the untreated heifers groups and treated during the antepartum. The test was performed in Minitab Software v.

\section{Results}

\section{Isolation profile of CoNS}

CoNS were the agents most frequently isolated throughout lactation on Farm 1 (Table 1). On Farm 2, CoNS predominated up to post-calving day 15 in the group of untreated animals, while in treated

\begin{tabular}{|c|c|c|c|c|c|c|c|}
\hline \multirow{3}{*}{ Collection } & \multicolumn{7}{|c|}{ PATÓGENOS } \\
\hline & CoNS & CoPS & Strep. spp & Cory. spp & Coccus spp spp - & S. aureus & Bacillus spp G- \\
\hline & N (\%) & $\mathbf{N}(\%)$ & $\mathbf{N}(\%)$ & N (\%) & $N(\%)$ & N (\%) & N (\%) \\
\hline Precalving & $46(28.75)$ & $11(6.88)$ & 0 & 0 & $3(1.88)$ & $1(0.63)$ & $3(1.88)$ \\
\hline Calving & $2(1.25)$ & 0 & 0 & 0 & 0 & 0 & 0 \\
\hline $3^{a}$ & $3(1.88)$ & 0 & $1(0.63)$ & 0 & 0 & $1(0.63)$ & 0 \\
\hline $4^{a}$ & $3(1.88)$ & 0 & $1(0.63)$ & $1(0.63)$ & 0 & 0 & 0 \\
\hline $5^{a}$ & $8(5.0)$ & 0 & 0 & 0 & 0 & 0 & 0 \\
\hline $6^{a}$ & $8(5.0)$ & 0 & $1(0.63)$ & $1(0.63)$ & 0 & 0 & 0 \\
\hline $7^{\mathrm{a}}$ & $7(4.38)$ & 0 & $1(0.63)$ & $1(0.63)$ & 0 & 0 & 0 \\
\hline $8^{a}$ & $6(3.75)$ & 0 & 0 & 0 & $1(0.63)$ & 0 & 0 \\
\hline $9^{a}$ & $5(3.13)$ & 0 & 0 & 0 & 0 & 0 & 0 \\
\hline $10^{\mathrm{a}}$ & $4(2.5)$ & 0 & $3(1.88)$ & $2(1.25)$ & $1(0.63)$ & $2(1.25)$ & 0 \\
\hline $11^{a}$ & $4(2.5)$ & 0 & 0 & 0 & 0 & 0 & 0 \\
\hline $12^{a}$ & $2(1.25)$ & 0 & 0 & 0 & 0 & 0 & 0 \\
\hline $13^{a}$ & 0 & 0 & 0 & 0 & 0 & 0 & 0 \\
\hline
\end{tabular}

$\mathrm{N}$ : absolute frequency, \%: relative frequency, CoPS: coagulase-positive Staphylococci; CoNS: coagulase-negative Staphylococci; ; S. aureus: Staphylococcus aureus Strep. spp: Streptococcus spp.; Cory. spp.: Corynebacterium spp.

Table 1: Absolute and relative frequency of microorganisms isolated from mammary secretions, colostrum and milk of heifers submitted to precalving treatment on Farm 1. 
Citation: Pilon LE, Castelani L, Santos AFS, Miranda MS, Ambrosio LA, et al. (2016) Identification of Bacterial Agents and Resistance Profile of Coagulase-Negative Staphylococci Isolated from Heifers Submitted or not to Precalving Treatment. J Vet Sci Technol 7: 390. doi: 10.4172/2157-7579.1000390

Page 3 of 6

animals the highest frequency of isolation of CoNS was observed during the precalving period. In untreated animals of Farm 3, the frequency of isolation of CoNS was higher at the end of lactation, while these pathogens predominated in treated animals until 200 days of lactation (Table 2).

\section{Microbiological profile of the farms}

Among the 160 mammary secretion samples collected from heifers during the precalving period on Farm 1, a higher frequency of isolation of CoNS (28.75\%). During lactation, the highest frequency of isolation of these pathogens occurred in the $5^{\text {th }}$ and $6^{\text {th }}$ sampling (Table 1 ). On Farm 2, the highest frequency of isolation of CoNS in the untreated and treated groups occurred during the precalving period $(88.89$ and $100 \%$, respectively), while during calving the frequency of these pathogens was 60.0 and $33.33 \%$ in the untreated and treated groups, respectively. During lactation, the highest frequency of isolation of CoNS in the untreated and treated groups was observed in the $7^{\text {th }}$ and $3^{\text {rd }}$ sampling (62.5 and $40 \%$, respectively).

On Farm 3, in the group of untreated animals, the frequency of isolation of CoPS was 69.24 and $39.28 \%$ during the precalving and calving period, respectively, followed by CoNS (15.38\% and $28.58 \%)$. In the treated group, CoPS were isolated from $100 \%$ of the samples during the precalving period. During the calving period, the frequency was $39.28 \%$ for CoPS and $25.0 \%$ for CoNS. During lactation, the pathogens showing the highest frequency of isolation in the untreated group were CoNS $(57.14 \%)$ in the $8^{\text {th }}$ sampling, followed by CoPS $(42.8 \%)$ in the $3^{\text {rd }}$ sampling. In the group of treated animals, the highest frequency of isolation of CoNS was found in the $9^{\text {th }}$ sampling $(80 \%)$, followed by CoPS in the $11^{\text {th }}$ sampling (33.3\%) (Table 2).

A significant difference between treated and untreated heifers (5\% level of significance) was observed for Staphylococcus aureus and Corynebacterium spp. on Farm 2 and for CoPS and Staphylococcus aureus on Farm 3 (Table 3). On Farm 2, the prevalence odds ratio of Staphylococcus aureus in untreated and treated heifers was 0.46 and was significant at the $5 \%$ level. Thus, the probability of occurrence of Staphylococcus aureus in the untreated group was $46 \%$ compared to the treated group. On Farm 3, the prevalence odds ratio of CoPS was
2.29 times higher in untreated heifers compared to the treated group. The prevalence odds ratio of Staphylococcus aureus was 2.45 and was significant at the $5 \%$ level. Thus, the prevalence of the pathogen was 2.45 times higher in the untreated group compared to the treated group (Table 4).

\section{Antimicrobial resistance profile of coagulase-negative Staphylococci}

The resistance rates of the CoNS strains isolated on Farm 1 were $16.98 \%$ for ampicillin, $13.21 \%$ for penicillin, and $3.77 \%$ for gentamicin. Important resistance against oxacillin $(2.83 \%)$ was also observed. High resistance against penicillin (31.03\%) was found on Farm 2, while $17.24 \%$ of the strains were resistant to oxacillin and, consequently, to all beta-lactam antibiotics. High resistance to penicillin (52.22\%) was observed on Farm 3 and $13.33 \%$ of the strains were resistant to oxacillin (Table 5).

\section{Discussion}

Coagulase-negative Staphylococci were the most frequent agents isolated from mammary secretions, colostrum and milk samples of heifers on Farm 1. The frequencies observed here were lower than those reported by Parker et al. [10] who evaluated 255 heifers during the precalving period and found a prevalence of CoNS of $10.4 \%$ in the samples. These authors also observed a reduction in the isolation of CoNS (4.5\% during calving) in animals receiving a teat sealant precalving. This rate is higher than that found on Farm 1 (1.25\%), probably because of the time of precalving infusion of the teat sealant which was 60 days on Farm 1. A predominance of CoNS (1.88\%) was observed on Farm 1 at approximately 15 days of lactation, while Parker et al. [10] analyzing milk samples of animals collected 14 days after calving, found $6.9 \%$ of CoNS in mammary quarters with mastitis. The post-calving result observed in the present study is lower than the rates reported by these authors. This difference may be related to the active ingredient and mode of action of the drugs as well as differences in the samples analyzed, since Parker et al. [11] only studied mammary quarters with mastitis.

The frequency of CoNS isolated on Farm 2 at approximately one of

\begin{tabular}{|c|c|c|c|c|c|c|c|c|c|c|c|c|c|c|c|}
\hline \multicolumn{16}{|c|}{ Farm 2} \\
\hline Untreated mammary & Precalving & Calving & $3^{a}$ & $4^{a}$ & $5^{a}$ & $6^{a}$ & $7^{\mathrm{a}}$ & $8^{a}$ & $9^{a}$ & $10^{\mathrm{a}}$ & $11^{\mathrm{a}}$ & $12^{\mathrm{a}}$ & $13^{a}$ & $14^{\mathrm{a}}$ & $15^{\mathrm{a}}$ \\
\hline CoPS & 11.11 & 40.00 & 28.57 & 57.14 & 50.00 & 0.00 & 37.50 & 0.00 & 50.00 & 0.00 & 0.00 & 0.00 & 0.00 & 0.00 & 0.00 \\
\hline CoNS & 88.89 & 60.00 & 42.86 & 28.57 & 25.00 & 0.00 & 62.50 & 0.00 & 0.00 & 0.00 & 0.00 & 0.00 & 0.00 & 0.00 & 0.00 \\
\hline S. aureus & 0.00 & 0.00 & 0.00 & 0.00 & 0.00 & 0.00 & 0.00 & 100.00 & 50.00 & 42.86 & 10.00 & 33.33 & 30.00 & 25.00 & 0.00 \\
\hline \multicolumn{16}{|l|}{ Treated mammary quarters } \\
\hline CoPS & 0.00 & 50.00 & 20.00 & 57.14 & 50.00 & 0.00 & 0.00 & 0.00 & 0.00 & 0.00 & 10.00 & 0.00 & 0.00 & 7.14 & 0.00 \\
\hline CoNS & 100.00 & 33.33 & 40.00 & 14.29 & 0.00 & 0.00 & 0.00 & 0.00 & 25.00 & 0.00 & 10.00 & 0.00 & 0.00 & 0.00 & 0.00 \\
\hline S. aureus & 0.00 & 33.33 & 40.00 & 14.29 & 0.00 & 0.00 & 0.00 & 0.00 & 25.00 & 0.00 & 10.00 & 0.00 & 0.00 & 0.00 & 0.00 \\
\hline \multicolumn{16}{|c|}{ Farm 3} \\
\hline Untreated mammary quarters & Precalving & Calving & $3^{a}$ & $4^{a}$ & $5^{a}$ & $6^{a}$ & $7^{a}$ & $8^{a}$ & $9^{a}$ & $10^{\mathrm{a}}$ & $11^{\mathrm{a}}$ & $12^{\mathrm{a}}$ & $13^{a}$ & $14^{\mathrm{a}}$ & $15^{\mathrm{a}}$ \\
\hline CoPS & 69.24 & 39.28 & 42.85 & 36.36 & 40.00 & 23.52 & 40.00 & 28.58 & 0.00 & 22.22 & 0.00 & 28.57 & 20.00 & 26.67 & 0.00 \\
\hline CoNS & 15.38 & 28.58 & 35.71 & 18.19 & 30.00 & 41.18 & 30.00 & 57.14 & 40.00 & 44.44 & 60.00 & 0.00 & 0.00 & 0.00 & 0.00 \\
\hline S. aureus & 15.38 & 10.71 & 7.14 & 0.00 & 0.00 & 5.90 & 0.00 & 0.00 & 0.00 & 11.12 & 10.00 & 35.71 & 20.00 & 6.66 & 0.00 \\
\hline \multicolumn{16}{|l|}{ Treated mammary quarters } \\
\hline CoPS & 100.00 & 39.28 & 15.50 & 0.00 & 9.09 & 16.66 & 0.00 & 0.00 & 0.00 & 0.00 & 33.33 & 0.00 & 0.00 & 10.00 & 25.00 \\
\hline CoNS & 0.00 & 25.00 & 30.75 & 25.00 & 27.27 & 50.00 & 50.00 & 71.44 & 80.00 & 42.85 & 0.00 & 60.00 & 50.00 & 10.00 & 0.00 \\
\hline S. aureus & 0.00 & 14.29 & 7.60 & 8.34 & 9.10 & 0.00 & 10.00 & 0.00 & 0.00 & 0.00 & 0.00 & 0.00 & 0.00 & 0.00 & 0.00 \\
\hline
\end{tabular}

CoPS: coagulase-positive Staphylococci; CoNS: coagulase-negative Staphylococci; S. Staphylococcus aureus.

Table 2: Relative frequency (\%) of Staphylococcus spp. isolated from milk samples collected from heifers during the precalving and calving period and during lactation on Farms 2 and 3. 
Citation: Pilon LE, Castelani L, Santos AFS, Miranda MS, Ambrosio LA, et al. (2016) Identification of Bacterial Agents and Resistance Profile of Coagulase-Negative Staphylococci Isolated from Heifers Submitted or not to Precalving Treatment. J Vet Sci Technol 7: 390. doi: 10.4172/2157-7579.1000390

Page 4 of 6

\begin{tabular}{|c|c|c|c|c|c|c|c|}
\hline \multirow[b]{2}{*}{ Isolates } & \multirow[b]{2}{*}{ Heifers } & \multicolumn{3}{|c|}{ Farm 2} & \multicolumn{3}{|c|}{ Farm 3} \\
\hline & & $\begin{array}{c}\text { Positive } \\
(\%)\end{array}$ & $\begin{array}{c}\text { Chi-square } \\
\left(x^{2}\right)\end{array}$ & $\mathbf{P}$ & $\begin{array}{l}\text { Positive } \\
\text { (\%) }\end{array}$ & $\begin{array}{c}\text { Chi-square } \\
\left(x^{2}\right)\end{array}$ & $\mathbf{P}$ \\
\hline \multirow{2}{*}{ Coagulase-positive Staphylococci } & Untreated & 18 & \multirow{2}{*}{$0.358 \mathrm{~ns}$} & \multirow{2}{*}{0.549} & 56 & \multirow{2}{*}{$12.174^{*}$} & \multirow{2}{*}{0.0001} \\
\hline & Treated & 13 & & & 26 & & \\
\hline \multirow{2}{*}{ Coagulase-negative Staphylococci } & Untreated & 24 & \multirow{2}{*}{$1.629 \mathrm{~ns}$} & \multirow{2}{*}{0.202} & 47 & \multirow{2}{*}{$0.274 \mathrm{~ns}$} & \multirow{2}{*}{0.601} \\
\hline & Treated & 14 & & & 43 & & \\
\hline \multirow{2}{*}{ S. aureus } & Untreated & 22 & \multirow{2}{*}{$8.512^{*}$} & \multirow{2}{*}{0.004} & 18 & \multirow{2}{*}{$4.767^{*}$} & \multirow{2}{*}{0.029} \\
\hline & Treated & 43 & & & 8 & & \\
\hline \multirow{2}{*}{ Corynebacterium spp. } & Untreated & 34 & \multirow{2}{*}{$3.829^{*}$} & \multirow{2}{*}{0.05} & ------- & \multirow{2}{*}{--------- } & \multirow{2}{*}{------ } \\
\hline & Treated & 17 & & & -ב----- & & \\
\hline \multirow{2}{*}{ Streptococcus spp. } & Untreated & 0 & \multirow{2}{*}{--------' } & \multirow{2}{*}{------ } & 40 & \multirow{2}{*}{$0.064 \mathrm{~ns}$} & \multirow{2}{*}{0.8} \\
\hline & Treated & 2 & & & 43 & & \\
\hline \multirow{2}{*}{ Coccus spp - } & Untreated & --------- & \multirow{2}{*}{ 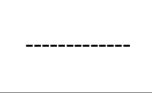 } & \multirow{2}{*}{---- } & 12 & \multirow{2}{*}{$3.044 \mathrm{~ns}$} & \multirow{2}{*}{0.081} \\
\hline & Treated & -------- & & & 5 & & \\
\hline \multirow{2}{*}{ Bacillus spp - } & Untreated & 2 & \multirow{2}{*}{$0.317 \mathrm{~ns}$} & \multirow{2}{*}{0.574} & 6 & (1) ד & \\
\hline & Treated & 3 & & & 11 & $1.391 \mathrm{~ns}$ & 0.23 \\
\hline
\end{tabular}

*: Significant difference between the treated and untreated groups $(p<0.05$. chi-square test).

ns: not significant

The dashed line indicates values of zero.

$P$ : probability value for the chi-square test

Table 3: Relative frequency (\%) of pathogens isolated from teat samples of treated and untreated heifers throughout the experiment and chi-square value.

\begin{tabular}{|c|c|c|c|c|c|c|c|c|}
\hline \multirow[b]{2}{*}{ Isolates } & \multicolumn{4}{|c|}{ Farm 2} & \multicolumn{4}{|c|}{ Farm 3} \\
\hline & Untreated & Treated & $\begin{array}{l}\text { Odds Ratio } \\
\text { (OR) }\end{array}$ & $\mathrm{Cl} 95 \%$ & Untreated & Treated & $\begin{array}{c}\text { Odds } \\
\text { Ratio } \\
\text { (OR) }\end{array}$ & $\mathrm{Cl} 95 \%$ \\
\hline $\begin{array}{c}\text { Coagulase-positive } \\
\text { SSSSSkSStaphylococci }\end{array}$ & $18^{\mathrm{a}}$ & $13^{\mathrm{a}}$ & 1.25 & $0.60-2.58$ & $56^{\mathrm{a}}$ & $26^{b}$ & 2.29 & $1.42-3.68$ \\
\hline Coagulase-negative Staphylococci & $24^{a}$ & $14^{\mathrm{a}}$ & 1.54 & $0.79-3.03$ & $47^{\mathrm{a}}$ & $43^{\mathrm{a}}$ & 1.12 & $0.73-1.72$ \\
\hline S. aureus & $22^{a}$ & $43^{b}$ & 0.46 & $0.27-0.78$ & $19^{a}$ & $8^{\mathrm{b}}$ & 2.45 & $1.07-5.64$ \\
\hline Corynebacterium spp & $34^{a}$ & $17^{\mathrm{b}}$ & 1.8 & $0.99-3.27$ & 0 & 0 & ------ & ----------- \\
\hline Streptococcus spp & 0 & 2 & ------ & ------- & $40^{\mathrm{a}}$ & $43^{a}$ & 0.94 & $0.61-1.47$ \\
\hline Coccus spp - . & 0 & 0 & ------- & ------- & $12^{\mathrm{a}}$ & $5^{\mathrm{a}}$ & 2.47 & $0.86-7.04$ \\
\hline Bacillus spp- . & $2^{\mathrm{a}}$ & $3^{a}$ & 0.6 & $0.10-3.61$ & $6^{a}$ & $11^{\mathrm{a}}$ & 0.55 & $0.2-1.50$ \\
\hline TOTAL & 455 & 410 & \multicolumn{2}{|c|}{----------------------' } & 765 & 779 & \multicolumn{2}{|c|}{------------------------ } \\
\hline
\end{tabular}

${ }^{a b}$ Frequencies in the same row followed by the same superscript letter do not differ from each other

Table 4: Absolute frequency, odds ratio and 95\% confidence interval of pathogens isolated from treated and untreated heifers (Farms 2 and 3 ).

week of lactation was $40 \%$. Similar results were obtained by Piepers et al. [11] evaluating 1,354 mammary quarters from all 344 heifers in the first week after calving study were infected 483 quarters (35.7\%) shortly after calving. Coagulase negative staphylococci were the most frequently isolated mastitis pathogens ( $\mathrm{n}=372 ; 77 \%$ of infected quarters) and the most frequent pathogens were CoNS $(\mathrm{n}=372,35.2 \%)$. On Farm 2, the variation in pathogens shown in Table 2 is related to the lack of hygiene during milking since no pre-milking teat dipping is performed. The purpose of this procedure is to eliminate pathogens present on the teat skin in order to minimize contamination of the milking equipment, consequently reducing the dissemination of microorganisms between animals.

Coagulase-negative Staphylococci are considered to be of low pathogenicity and usually cause subclinical infections. However, intramammary infections in first-lactation animals can affect 10 to $20 \%$ of mammary quarters. The heifers can show a high frequency of mastitis caused by CoNS after calving, followed by a rapid decline in cases after the second week of lactation [12]. This fact was not observed in the present study in which CoNS predominated throughout lactation. As can be seen in Table 2, the frequency of CoNS was high during calving (28.58\%) and these pathogens continued to be isolated throughout lactation, except for the $12^{\text {th }}$ to $15^{\text {th }}$ sampling, with a peak isolation rate of $80 \%$ at 200 days of lactation. The moment of bacteriological colonization and kind of pathogen involved do have an effect on the udder health during first lactation, and the mammary glands of heifer may harbor bacteria precalving, an observation that is supported by the results of the present study [13].

A significant difference (5\% level of significance) in the relative frequency of pathogens between untreated and treated animals was observed for $S$. aureus $(\mathrm{P}=0.004)$ and Corynebacterium spp. $(\mathrm{P}=0.05)$ 
Citation: Pilon LE, Castelani L, Santos AFS, Miranda MS, Ambrosio LA, et al. (2016) Identification of Bacterial Agents and Resistance Profile of Coagulase-Negative Staphylococci Isolated from Heifers Submitted or not to Precalving Treatment. J Vet Sci Technol 7: 390. doi: 10.4172/2157-7579.1000390

Page 5 of 6

on Farm 2, and for CPS $(\mathrm{P}=0.0001)$ and $S$. aureus $(\mathrm{P}=0.029)$ on Farm 3 (Table 3). As can be seen in Table 4, there was a significant difference between the untreated and treated groups in the absolute frequency (with $95 \%$ confidence interval) of $S$. aureus (22 and 43 ) and Corynebacterium spp. (34 and 17) on Farm 2, and of CoPS (56 and 26) and $S$. aureus (16 and 8) on Farm 3. The pathogens isolated on Farms 2 and 3 are the causative agents of contagious mastitis, i.e., they are transmitted during milking management. The results suggest that the farms should improve their good milking practices since, according to Zafalon et al. [14], farms employing good milking practices reduce transmission of the infectious agents responsible for bovine mastitis. Another approach of dairy farms to reduce the bacterial load in the mammary gland of heifers is to set up a milking line, i.e., to milk primiparous heifers first since this milking management reduces the transmission of mastitis-causing pathogens from cows to heifers.

Coagulase-negative Staphylococci are a common member of the skin microbiota and, by living in balance with this ecosystem, have been described as virulent microorganisms. Progress in the identification of genera, species and subspecies of pathogens has been made over the last decade, permitting clinicians to identify the variety of CoNS present in clinical samples and to imply these microorganisms as the etiological agents of a series of infections. In this respect, CoNS have been the main pathogens isolated from the mammary quarters of animals with mastitis $[15,16]$.

Infections caused by CoNS have been increasing, a fact leading researchers to study existing species which are responsible for different diseases in animals. Animals carrying oxacillin-resistant CNS strains do not respond to treatment with beta-lactam antibiotics except new cephalosporin classified as $\mathrm{V}$ generation (ceftobiprole) This resistance is associated with transpeptidase PBP2a no methicilin resistent Staphylococcus aureus (MRSA) and methicilin resistant coagulase negative Staphylococci (MR-CoNS) [17].

The resistance rate of CoNS strains isolated on Farm 1 was 16.98\% for ampicillin, $13.21 \%$ for penicillin, and $3.77 \%$ for gentamicin. Important resistance to oxacillin (2.83\%) was also observed (Table 5). Soares [18] studied lactating cows and found high resistance of CNS strains to different antimicrobials: penicillin (79\%), ampicillin (79\%), tetracycline (64\%) and oxacillin (29\%). These rates are much higher than those observed in the present study involving heifers and the microbial load of resistant bacteria may increase over time in these animals.

High resistance to penicillin (31.03\%) was observed on Farm 2, while $17.24 \%$ of the strains were resistant to oxacillin and consequently to all beta-lactam antibiotics. Karabasanavar and Singh [19] found strains resistant to penicillin (99.9\%), amoxicillin (63.7\%) and oxytetracycline (63.7\%), and $100 \%$ of the strains revealed resistance to erythromycin, amikacin and nitrofurantoin. The high resistance to antimicrobials is associated, according to the authors, the indiscriminate use of antibiotics in India.

On Farm 3, high resistance to penicillin was observed (52.22\%) and $13.33 \%$ of the strains were resistant to oxacillin. Frey et al. [20] founded 417 coagulase-negative staphylococci in milk samples from cows with clinical and subclinical mastitis (370) 47\% de CoNS oxacillin resistance,

\begin{tabular}{|c|c|c|c|c|c|c|}
\hline \multicolumn{7}{|c|}{ FARM 1} \\
\hline \multirow{3}{*}{ Active principle } & \multicolumn{6}{|c|}{ Profile } \\
\hline & \multicolumn{2}{|c|}{ Resistance } & \multicolumn{2}{|c|}{ Intermediateo } & \multicolumn{2}{|c|}{ Susceptibility } \\
\hline & $\mathbf{N}$ & $\%$ & $\mathbf{N}$ & $\%$ & $\mathbf{N}$ & $\%$ \\
\hline Florfenicol $30 \mu \mathrm{g}$ & 4 & 3.77 & 2 & 2.12 & 100 & 94.34 \\
\hline Ampicillin $10 \mu \mathrm{g}$ & 18 & 16.98 & - & ---- & 88 & 83.02 \\
\hline Cephalexin $30 \mu \mathrm{g}$ & 4 & 3.77 & - & ----- & 102 & 96.23 \\
\hline Ceftiofur $30 \mu \mathrm{g}$ & 3 & 2.83 & - & ---- & 103 & 97.17 \\
\hline Penicillin $10 \mu \mathrm{g}$ & 14 & 13.21 & - & ---- & 92 & 86.79 \\
\hline Neomycin $10 \mu \mathrm{g}$ & - & ---- & - & ----- & 106 & 100.00 \\
\hline Oxacillin $1 \mu \mathrm{g}$ & 3 & 2.83 & - & ----- & 103 & 97.17 \\
\hline Gentamicin $10 \mu \mathrm{g}$ & 4 & 4.24 & - & ---- & 102 & 96.23 \\
\hline \multicolumn{7}{|c|}{ FARM 2} \\
\hline Florfenicol $30 \mu \mathrm{g}$ & 5 & 17.24 & - & ----- & 24 & 82.76 \\
\hline Ampicillin $10 \mu \mathrm{g}$ & 5 & 17.24 & - & ---- & 24 & 82.76 \\
\hline Cephalexin $30 \mu \mathrm{g}$ & 5 & 17.24 & - & ---- & 24 & 82.76 \\
\hline Ceftiofur30 $\mu \mathrm{g}$ & 5 & 17.24 & 2 & 6.90 & 22 & 75.86 \\
\hline Penicillin $10 \mu \mathrm{g}$ & 9 & 31.03 & - & ---- & 20 & 68.97 \\
\hline Neomycin $10 \mu \mathrm{g}$ & 0 & 0.00 & 1 & 3.45 & 28 & 96.55 \\
\hline Oxacillin $1 \mu \mathrm{g}$ & 5 & 17.24 & - & ----- & 24 & 82.76 \\
\hline Gentamicin $10 \mu \mathrm{g}$ & 5 & 17.24 & - & ---- & 24 & 82.76 \\
\hline \multicolumn{7}{|c|}{ FARM 3} \\
\hline Florfenicol $30 \mu \mathrm{g}$ & 12 & 13.33 & - & ----- & 78 & 86.67 \\
\hline Ampicillin $10 \mu \mathrm{g}$ & 12 & 13.33 & - & ---- & 78 & 86.67 \\
\hline Cephalexin $30 \mu \mathrm{g}$ & 12 & 13.33 & - & ---- & 78 & 86.67 \\
\hline Ceftiofur30 $\mu \mathrm{g}$ & 12 & 13.33 & 6 & 6.67 & 72 & 80.00 \\
\hline Penicillin $10 \mu \mathrm{g}$ & 47 & 52.22 & - & ---- & 43 & 47.78 \\
\hline Neomycin $10 \mu \mathrm{g}$ & 1 & 1.11 & 2 & 2.2 & 87 & 96.67 \\
\hline Oxacillin $1 \mu \mathrm{g}$ & 12 & 13.33 & - & ----- & 78 & 86.67 \\
\hline Gentamicin $10 \mu \mathrm{g}$ & 12 & 13.33 & - & ---- & 78 & 86.67 \\
\hline
\end{tabular}

Table 5: Antimicrobial resistance profile of coagulase-negative Staphylococci isolated from mammary quarter milk samples of heifers during the precalving and post-calving period and during lactation on Farms. 
Citation: Pilon LE, Castelani L, Santos AFS, Miranda MS, Ambrosio LA, et al. (2016) Identification of Bacterial Agents and Resistance Profile of Coagulase-Negative Staphylococci Isolated from Heifers Submitted or not to Precalving Treatment. J Vet Sci Technol 7: 390. doi: 10.4172/2157-7579.1000390

Page 6 of 6

which is the indicator of MEC gene-mediated methicillin resistance. As a consequence, these animals did not respond to treatment with betalactam antibiotics as reported by Mlynarczyk et al. [17]. The drug used for the precalving treatment of heifers was penicillin, an antibiotic to which CoNS were highly resistant $(52.22 \%)$. This fact may explain the low treatment response of heifers in the treated group compared to untreated animals during the precalving and calving period. Precalving intramammary infusion of antibiotics should not be performed indiscriminately as a routine procedure without knowledge of the microbiological and antibiotic susceptibility profile.

Tarazi et al. [21] found $23 \%$ of strains resistant to penicillin, lincomycin $25 \%$, gentamycin $20 \%$, cephalexin $13 \%$, ciprofloxacin $10 \%$. Strains resistant to neomycin (10\%) and ampicillin (5\%) were also isolated from secretions of mammary quarters of heifers $(n=56)$ in the pre calving, colostrum and regular lactation. Similar results were obtained in the present study on Farms 1, 2 and 3, which demonstrate that heifers need to be given more importance since, as the future of the herd, they should not carry a high frequency of resistant strains at the beginning of lactation.

The high level of resistance among pathogens on the three farms studied should serve as a warning to professionals when prescribing antimicrobial drugs to animals with mastitis [22]. Precalving treatment of heifers may select antibiotic-resistant CNS strains, causing harm to animals and resulting in losses for producers, and could become a public health problem.

\section{Conclusions}

The isolation of mastitis-causing infectious agents from mammary secretions of heifers during the precalving and calving period indicates that these animals may become a source of infection in the herd. The presence of oxacillin-resistant CoNS in heifers may affect mastitis treatment in subsequent lactations. Precalving treatment with intramammary antibiotics should be done with caution and should be preceded by microbiological tests and antibiograms to permit the correct use of antimicrobial agents and to obtain the best response to treatment. Antibiotics should not be used indiscriminately as routine treatment on dairy farms.

\section{References}

1. Fox LK (2009) Prevalence, incidence and risk factors of heifer mastitis. Vet Microbiol 134: 82-88.

2. De Vliegher S, Fox LK, Piepers S, McDougall S, Barkema HW (2012) Invited review: Mastitis in dairy heifers: Nature of the disease, potential impact, prevention, and control. J Dairy Sci 95: 1025-1040.

3. Nigam D (2015) Microbial Interactions with Humans and Animals. Inter J Microbiol Allied Sci 2: 1-17.

4. Zhou X, Yang C, Li Y, Liu X, Wang Y (2015) Potential of berberine to enhance antimicrobial activity of commonly used antibiotics for dairy cow mastitis caused by multiple drug-resistant Staphylococcus epidermidis infection. Genet Mol Res 14: 9683-9692.

5. Oliver SP, Gonzalez RN, Hogan JS, Jayarao BM, Owens WE (2004) Microbiological procedures for the diagnosis of bovine udder infection and determination of milk quality. Verona WI, USA: National Mastitis Council.

6. Holmberg O (1973) Staphylococcus epidermidis isolated from bovine milk. Biochemical properties, phage sensitivity and pathogenicity for the udder. Acta Vet Scand 45: 1-144.

7. Collins MD, Cumminis CS (1986) Genus Corynebacterium Lehmann and Neumann. In: Bergey's Manual of Systematic Bacteriology. Brenner DJ, Krieg NR, Staley JT (Eds.). Springer publications, USA, 2: 1266-1276.

8. Clinical and Laboratory Standards Institute (CLSI) (2011) Performance standards for antimicrobial susceptibility testing. 21st Informational Supplement. Wayne, Pennsylvania, USA.
9. Rumel D (1986) “ Odds ratio”: algumas considerações. Rev Saude Publica 20 : 253-258.

10. Parker KI, Compton C, Annissf M, Weir A, Heuer C, et al. (2007) Subclinical and clinical mastitis in heifers following the use of a teat sealant precalving. $J$ Dairy Sci 90: 207-218.

11. Parker KI, Compton CWR, Anniss FM, Heuer C, McDougall S (2008) Quarterlevel analysis of subclinical and clinical mastitis in primiparous heifers following the use of a teat sealant or an injectable antibiotic, or both, precalving. J Dairy Sci 91: 169-181.

12. Pozzi CR, Santos AFS, Martins T, Oltramari CE, Ambrósio LA, et al. (2014) Antimicrobial residues in milk and occurrence of clinical and subclinical mastitis in herds in the region of Campinas, São Paulo. Acta Veterinaria Brasilica 8: 60-67.

13. Krömker V, Friedrich J (2009) Teat canal closure in non-lactating heifers and its association with udder health in the consecutive lactation. Vet Microbiol 134 100-105.

14. Zafalon LF, Arcaro JRP, Nader Filho A, Ferreira LM, Castelani L, et al. (2008) Investigação de perfis de resistência aos antimicrobianos em Staphylococcus aureus isolados na ordenha de vacas em lactação. Rev. Inst. Adolfo Lutz (Impr) 67: 118-125.

15. Paradis MĖ, Bouchard É, Scholl DT, Miglior F, Roy JP (2010) Effect of nonclinical Staphylococcus aureus or coagulase-negative staphylococci intramammary infection during the first month of lactation on somatic cell count and milk yield in heifers. J Dairy Sci 93: 2989-2997.

16. Silva NC, Guimaraes FF, Manzi MDP, Gómez-Sanz E, Gómez P, et al. (2014) Characterization of methicillin-resistant coagulase-negative staphylococci in milk from cows with mastitis in Brazil. Antonie van Leeuwenhoek 106: 227-233.

17. Mlynarczyk A, Mlynarczyk B, Kmera-Muszynska M, Majewski S, Mlynarczyk G (2009) Mechanisms of the resistance and tolerance to beta-lactam and glycopeptide antibiotics in pathogenic Gram-positive cocci. Mini Rev Med Chem 9: 1527-1537.

18. Soares LC, Pereira IA, Pribul BR, Oliva MS, Coelho SM, et al. (2012) Antimicrobial resistance and detection of mecA and blaZ genes in coagulasenegative Staphylococcus isolated from bovine mastitis. Pesq Vet Bras 32: 692696.

19. Karabasanavar NS, Singh SP (2013) Isolation and antibiograms of coagulase negative Staphylococci from bovine mastitis milk. J Foodborne Zoonotic Dis 1: 21-23.

20. Frey Y, Rodriguez JP, Thomann A, Schwendener S, Perreten V (2013) Genetic characterization of antimicrobial resistance in coagulase-negative staphylococci from bovine mastitis milk. J Dairy Sci 96: 2247-2257.

21. Tarazi-All YH, Chakiso AY, Lafi SQ (2011) Prevalence and Distribution of Bovine Mastitis Pathogens and their Antimicrobial Resistance in Primiparous Dairy Heifers in Northern Jordan. Jordan J Agr Sci 7: 529-538.

22. Piepers S, Schukken YH, Passchyn P, De Vliegher S (2013) The effect of intramammary infection with coagulase-negative staphylococci in early lactating heifers on milk yield throughout first lactation revisited. J Dairy Sci 96: 5095-5105. 